\title{
Group Cohesion and Learning Opportunities in Peer Interaction
}

\author{
Carolyn E. Leslie \\ Universidade Nova de Lisboa
}

Received: 28 June 2017 / Accepted: 09 October 2017

ISSN: 1697-7467

\begin{abstract}
The present study investigates peer to peer oral interaction in two task based English as a foreign language classrooms, one of which was a self-declared cohesive group, and the other a self-declared less cohesive group. The objective of the study was to investigate how learning opportunities were talked into being through peer to peer interactions in these two groups and to determine how the cohesive or less cohesive nature of the class influenced the number of learning opportunities in peer interaction. The study was classroombased and was carried out over the period of an academic year. Research was framed within a sociocognitive perspective of language learning and data was collected from questionnaires and audio recorded talk of dyads, triads and groups of four students completing a total of eight oral tasks. Using conversation analysis, these audio recordings were transcribed and analysed quantitatively for learning opportunities and qualitatively for interactions which encouraged a positive social dimension and which may have led to the creation of learning opportunities. Analysis of interactions revealed the many ways in which learners in both the cohesive and less cohesive class created learning opportunities. Further qualitative analysis of these interactions showed how the affective relationship between participants influenced the number of learning opportunities created.
\end{abstract}

Keywords: peer oral interaction, cohesive groups, learning opportunities, sociocognition, situated nature of language learning.

\section{Cohesión grupal y oportunidades de aprendizaje en interac- ción entre pares}

RESUMEN: El presente estudio investiga la interacción oral entre pares en dos grupos de inglés como lengua extrajera basados en el enfoque por tareas, uno de ellos autodenominado como un grupo cohesionado, mientras que el otro se declara como grupo menos cohesionado. El objetivo es investigar cómo se crean oportunidades de aprendizaje a través de la interacción, y determinar cómo la naturaleza más o menos cohesiva del grupo influye en el número de oportunidades de aprendizaje entre pares. El estudio está basado en las actividades realizadas en el aula durante un año académico. La investigación se encuadra dentro de una perspectiva sociocognitiva de aprendizaje de una segunda lengua y los datos provienen de cuestionarios y grabaciones audio de grupos de estudiantes que completaron ocho tareas orales. A partir del análisis conversacional, estas grabaciones han sido transcritas y analizadas de modo cuantitativo en relación con las oportunidades de aprendizaje y de manera cualitativa para las interacciones que fomentan una dimensión social positiva y conducen a oportunidades de aprendizaje. El 
análisis de interacciones revela la variedad de maneras mediante las cuales los estudiantes de ambos grupos crean oportunidades de aprendizaje. Análisis cualitativos adicionales demuestran cómo la relación afectiva entre participantes influye en la cantidad de oportunidades de aprendizaje creadas.

Palabras clave: interacción oral entre pares, grupos cohesivos, oportunidades de aprendizaje, sociocognición, naturaleza situada del aprendizaje de una lengua.

\section{Introduction and Theoretical Framework}

Traditionally language learning was viewed as the transmission of knowledge from teacher to learner, and peer interaction ${ }^{1}$ in the language classroom was not considered a context for learning. Perhaps for this reason, research into peer interaction has received much less attention from researchers than has interaction between learners and native speakers or teachers (Sato \& Ballinger, 2016). However, a belief that learner output could be increased if learners were given the opportunity to talk to each other has led to increased interest in peer interaction as a context for language practice and use (Philp, Adams \& Iwashita, 2014). Presently, socio-cognitive views of learning, based principally on the work of Vygotsky (1987), suggest that learning is situated in social interaction and practice, with some researchers believing that learning does not occur through interaction, but that "what occurs in collaborative dialogues is learning" (Swain \& Lapkin, 1998:321).

This increased emphasis on interaction in the language classroom has led to an increased awareness of the social dimension. Mondada and Pekarek Doehler (2004) suggest the importance of considering the social realm in learning not as the backdrop to activities, but as an integral part of learning. This idea is echoed in Larsen-Freeman's complexity theory which views context as part of the complex system, with different social contexts resulting in different performances (2010).

From the point of view of the teacher, attention to the social dimension in language classrooms is important for the creation of the necessary conditions for more effective learning. Furthermore, encouraging positive emotions such as motivation or self-esteem can "greatly facilitate the language learning process" (Arnold \& Brown, 1999:2). Senior (1997) described how the teachers she questioned felt a necessity to foster and maintain a positive whole group feeling amongst learners, and noted the importance of the bonded group as being one that is considered to function in "a cohesive manner" as this was "a necessary precondition for the development of linguistic proficiency through oral practice" (1997:4).

In the area of small group research, group cohesion is generally associated with the whole group and refers to "the strength of the relationship linking the members to one another and to the group itself " (Forsyth 1991:10). It has been found to be positively correlated to group performance, with cohesive groups tending to work more productively (Evans \& Dion, 1991), and more productive groups being more cohesive (Swezey, Meltzer \& Salas, 1994). Peer to peer interaction is also thought to be enhanced by a cohesive group climate,

\footnotetext{
${ }^{1}$ Defined by Philp, Adams \& Iwashita (2014: 3) as "any communicative activity carried out between learners, where there is minimal or no participation from the teacher."
} 
and Levine and Moreland's review of the literature regarding small group research (1990) confirms that members of a cohesive group are more likely than others to take an active part in conversation and engage in self-disclosure (both of which are advantageous in communicative language tasks). Slavin (1996:46) believes that cohesion promotes learning, as "students will help one another learn because they care about one another and want one another to succeed". In the language classroom, group cohesion has been identified as a motivational subsystem, which in conjunction with self-confidence and integrative motivation makes up the Clement, Dornyei and Noels motivational model (1994). It could also be suggested that as the members of cohesive groups are more likely to positively regard other group members due to perceived similarity and mutual acceptance (Ehrman \& Dornyei 1998), a more positive social dimension could be created in cohesive groups, which could lead to greater social engagement, and consequently more effective language learning (Philp \& Duchesne,2016: 10). It would appear that positive group processes such as whole group cohesion can have a beneficial effect on the motivation of learners and engender positive attitudes,but even though research on cohesion in areas such as business and sport has shown promising results, empirical research in the area of group cohesion and language learning classes "remains scarce" (Chang, 2007:324).

Research into peer interaction has traditionally been investigated from a cognitive perspective, highlighting the importance of input (Krashen, 1982), output (Swain, 1995), interaction (Long, 1996) and corrective feedback (for a review see Lyster, Saito \& Sato, 2013). However it has also been examined from a sociocultural perspective, based principally on the work of Vygotsky (1987) and Leontiev (1981), who view development as taking part in a social activity rather than acquiring knowledge. Although both are useful in different ways, both "impose certain limitations on data analysis" (Sato \& Ballinger, 2016:13), and for this reason the research here is framed in a sociocognitive framework.

\subsection{Aim of the Study}

Oral interactions in the language learning classroom are simultaneously the object of study, the means through which learning takes place, the source of emotional experiences and the vehicle of group building. As a learner's utterance "documents the learner's cognitive, emotional and attitudinal states" (Seedhouse, 2005:178), the aim of this study is to examine the oral interactions of learners in cohesive and less cohesive language learning classes to investigate the relationship between whole group cohesion, and the creation of learning opportunities. Here an emic perspective was adopted, which studies behaviour as from inside the system (Seedhouse 2004: 4), and analyses how learners orient to potential moments of learning created during the unfolding interaction. In this way learning "can be seen in an active way, in the process of performing tasks" where "task-specific learning potentials emerge from the turn-by-turn collaborative accomplishment of a given task" (Hellermann \& Pekarek Doehler 2010:28). As such learning opportunities or learning potentials emerge from the interaction, they vary according to participants and tasks, but Hellermann and Pekarek Doehler (2010) identify features such as word searches, repair sequences, coconstruction, and explaining using alternative wording. Learning opportunities mentioned by Canico (2015) include confirmation checks, requests for clarification and content feedback. 
Thus, the aim of the study is to determine:

- How learning opportunities are talked into being in peer interactions in cohesive and less cohesive classes.

- If oral interaction amongst peers in more cohesive groups promotes learning through the creation of more learning opportunities than in less cohesive groups.

\section{Methods}

\subsection{Context and Learners}

The learners involved in this study were adults who attended EFL classes once a week at a language school in Lisbon, Portugal. All learners were native speakers of Portuguese. Six classes at B1 level, (Council for Cultural Co-operation Education Committee, 2001) were initially involved. The pedagogical approach to teaching could be described as task-supported language teaching (Ellis, 2003), where tasks were incorporated into traditional language based courses with textbook materials being adapted and supplemented with authentic reading and listening texts. One limitation of this study was its situated nature and reduced number of participants. As such, it aims to provide a detailed understanding of how learning opportunities emerged during face-to-face talk amongst members of these groups.

\subsection{The Questionnaire}

A questionnaire, (Appendix 1) based on that of Chang (2007), was distributed to learners in all six classes at the end of term one and again at the end of term three to measure whole group cohesion. A 5 point Likert scale was used to analyse results, and the mean was then calculated for each of the eleven questions per group and added to give an overall score per class, which served as an indicator of whole group cohesion. Similarly, questionnaires were distributed to the teachers of the six classes (Appendix 2), asking them to assess how cohesive they judged their classes to be.

\subsection{Tasks and Recordings}

Tasks used in this study were prepared by the researcher to complement classroom work and were introduced to learners by the class teacher as part of their everyday classwork. In total eight tasks were used over the academic year. Tasks 1 and 6 were both discussion/error correction tasks of the type Ellis refers to as consciousness-raising tasks, where the focus of the task is the language itself (2003). Tasks 2 and 8 were dictogloss tasks, a reconstruction task believed to promote noticing (Wajnryb, 1990). Task 3 was a focus on form writing task, and tasks 4 and 5 were both unfocused discussion tasks. Recordings of students taking part in these oral tasks were carried out in intact classes. Two groups of between 2 and 4 students were chosen randomly in each class and recorded simultaneously and in the same

\section{8}


room for the duration of the task, which on average lasted approximately 15 minutes, using two voice recorders which were placed on the table in front of the students.

\subsection{Analysis of Recordings for Learning Opportunities}

Interactions in the classroom were transcribed, and selected episodes re-transcribed and analysed using conventions from Conversation Analysis (CA). The data was examined with an open mind, termed "unmotivated looking" (Seedhouse, 2004:38), for behaviours leading to learning opportunities, using function to guide coding. Appendix 3 sets out the Transcription key used in this study. Transcripts were also analysed quantitatively for learning opportunities by counting the number of opportunities identified per task. Although the quantification of data in CA has been controversial, Foster and Ohta (2005) note that quantification can be used to gain further insight into sociocultural approaches, but stress that the categories for quantification must emerge from the data rather than being imposed a priori by the researcher.

\section{RESULTS}

\subsection{Questionnaires}

Two class groups, henceforth referred to as Class 1 and Class 2, which were taught by the same teacher, were consistently identified both times the questionnaire was distributed as respectively the most and least cohesive groups by teachers and students alike. When mean scores for Class 1 and Class 2 were compared, it was clear why learners in Class 1 considered their group to be more cohesive. In term 1, of the 11 items, scores for all except one (item 8) were higher in Class 1 . The greatest difference could be seen in item 10 (There are some classmates I prefer not to work with) suggesting that whereas the members of Class 1 were generally prepared to work with all other group members, this was not the case for Class 2, indicating less acceptance of other group members and one possible reason for less group cohesion. At the end of term 3, scores showed that whereas group cohesion had grown over time in Class 1, cohesion in Class 2 had remained unchanged suggesting that Class 2 had failed to mature into a cohesive group.

\subsection{Qualitative Analysis for Learning Opportunities}

The sociocognitive framework used here to study L2 interaction analysed how learners worked in their zones of proximal development to achieve their goals. Qualitative analysis of transcripts showed how interaction in both pairs and small groups provided plentiful opportunities for learning as students engaged with tasks. Table 1 below sets out the learning opportunities identified and gives a description or an example of use in the interaction. 
Table 1 Learning Opportunities in the interaction

\begin{tabular}{|c|c|}
\hline Learning Opportunities & Description/Example \\
\hline Languaging $^{2}$ & Talking through what is cognitively challenging. \\
\hline Private Speech ${ }^{3}$ & $\begin{array}{l}\text { Self-addressed language produced either when the learner is } \\
\text { alone or in the presence of others. }\end{array}$ \\
\hline Peer repair & Explicit correction or implicit correction through recasts. \\
\hline Self- Repair & Learners' self- initiated correction. \\
\hline Co-construction ${ }^{4}$ & $\begin{array}{l}\text { '[...] they played with the some, not the calf skin but the,' } \\
\text { 'Oh, leather' } \\
\text { 'The leather, yes }[\ldots]\end{array}$ \\
\hline Metalanguage & $\begin{array}{l}\text { '[...] por acaso não punha o }((\text { tra.: in fact I wouldn't put the })) \\
\text { past perfect.' }\end{array}$ \\
\hline $\begin{array}{l}\text { Asking others (students and teach- } \\
\text { er) }\end{array}$ & $\begin{array}{l}\text { 'by a Scottish. how do I write?' } \\
\text { 'mary, we have a doubt' }\end{array}$ \\
\hline Explaining & $\begin{array}{l}\text { 'so if you won a lot of money you would move house. I think } \\
\text { this is incorrect [...] because when you do the question you put } \\
\text { would first, would you' }\end{array}$ \\
\hline Translation & 'learning it's aprender.' \\
\hline Testing hypotheses/suggesting & $\begin{array}{l}\text { 'can be I have met?' } \\
\text { 'no, é so ((tra.: no it's only)) I met.' }\end{array}$ \\
\hline Use of coursebooks/notes & $\begin{array}{l}\text { 'interesting in, was one of the workbook exercises, interesting } \\
\text { in, page 35' }\end{array}$ \\
\hline Overhearing & Overhearing the interaction of others. \\
\hline
\end{tabular}

These opportunities were at times realised collaboratively, other times individually and occurred both during focus on form and oral discussion tasks.

\subsection{Quantitative Analysis of Leaning Opportunities}

As mentioned in section 2.4, transcripts were analysed quantitatively for learning opportunities by counting the number of opportunities identified by task. Due to technical

\footnotetext{
${ }^{2}$ Swain (2010:115) believes that languaging allows "further elaboration and shaping of the now realized ideas."

${ }^{3}$ Self- addressed language which includes repetition, imitation and solitary language play (Ohta, 2001).

${ }^{4}$ Described by Ohta (2001:91) as "chiming in with the next word or phrase."
} 
difficulties or problems of operationalization, languaging, private speech, and overhearing the utterances of other learners were not quantified in the data. Table 2 shows the data for the quantitative analysis of the other learning opportunities identified above by class and task. Data for task 3 was discounted as the class teacher gave differing instructions to each of the two groups.

Table 2 Number of learning opportunities created by class and task.

\begin{tabular}{|c|c|c|}
\cline { 2 - 3 } \multicolumn{1}{c|}{} & \multicolumn{2}{c|}{ Learning Opportunities } \\
\hline Task & Class 1 & Class 2 \\
\hline 1 & 126 & 78 \\
\hline 2 & 18 & 20 \\
\hline 3 & - & - \\
\hline 4 & 53 & 73 \\
\hline 5 & 60 & 55 \\
\hline 6 & 30 & 74 \\
\hline 7 & 10 & 37 \\
\hline 8 & 81 & 117 \\
\hline
\end{tabular}

Contrary to expectations, Figure 1 shows that Class 2, the less cohesive group, scored higher for the creation of learning opportunities in all of the tasks with the exception of tasks 1 and 5. Although both students and the teacher consistently scored Class 1 as being more cohesive over the academic year, learners in this group created fewer learning opportunities than those in Class 2, the less cohesive group.

In an effort to understand these results, transcripts of talk in interaction were analysed qualitatively using conventions from Conversation Analysis ${ }^{5}$ for tasks which revealed the greatest differences, namely tasks 1, 6, and 7, and these are shown below in section 3.4. All names used are pseudonyms.

\subsection{Qualitative Analysis of Transcripts}

\subsubsection{Task 1}

In Task 1, the number of learning opportunities created by learners in Class 1, the more cohesive group, was higher than the number of learning opportunities created by learners in Class 2, as expected. Excerpt 1 shows Class 1 students Anna, Silvia and Rita, correcting the sentence 'We didn't knew that the train was late' in Task 1.

\footnotetext{
${ }^{5}$ Conversation Analysis is a methodology that tries to explain the details of interaction and to "uncover the communicative and social competences that structure and render meaningful talk-in-interaction" (Firth \& Wagner, 2007: 813).
} 
(1)

\begin{tabular}{|c|c|c|c|}
\hline$\rightarrow$ & 55 & $\mathrm{~S}$ & we didn't knew, (.) that the train was late. \\
\hline$\rightarrow$ & 56 & $\mathrm{R}$ & ${ }^{\circ} \mathrm{ok}^{\mathrm{O}}$. \\
\hline$\rightarrow$ & 57 & $\mathrm{~S}$ & the mi:stake here (.) is (1) two past. didn't, and knew! \\
\hline & 58 & A & ${ }^{\circ}$ knew $^{\circ}$ \\
\hline$\rightarrow$ & 59 & $\mathrm{~S}$ & $>$ we didn't know $<$. \\
\hline$\rightarrow$ & 60 & $\mathrm{R}$ & (5) sorry say that \\
\hline$\rightarrow$ & 61 & $\mathrm{~S}$ & $i$ think we have [ $\underline{\text { two }}$ of the time past.] \\
\hline & 62 & A & {$\left[{ }^{\circ}\right.$ in the, the $\left.{ }^{00}\right]$} \\
\hline & 63 & $\mathrm{~S}$ & yes! we have ( ). \\
\hline & 64 & $\mathrm{R}$ & knew in the present \\
\hline$\rightarrow$ & 65 & $\mathrm{~S}$ & you alr...you still have the past in $\underline{\text { didn't }}$ \\
\hline$\rightarrow$ & 66 & $\mathrm{R}$ & so it's correct. \\
\hline$\rightarrow$ & 67 & $\mathrm{~S}$ & knew is (1) is not correct \\
\hline & 68 & $\mathrm{R}$ & (2) ah ok \\
\hline$\rightarrow$ & 69 & $\mathrm{~S}$ & we didn't know. \\
\hline$\rightarrow$ & 70 & $\mathrm{R}$ & it's in the present. \\
\hline & 71 & A & that the train [was late.] \\
\hline$\rightarrow$ & 72 & $\mathrm{R}$ & {$\left[{ }^{\circ} \mathrm{ok}^{\mathrm{o}}\right]$} \\
\hline
\end{tabular}

In line 55 Silvia reads the sentence to be corrected which Rita acknowledges on line 56. In line 60 Rita asks for clarification and in lines 61 and 65 Silvia provides an explanation of her correction. Throughout the sequence Silvia assumes the role of language expert and establishes a joint understanding of the problem, further emphasised by her use of 'we' in lines 61 and 63, highlighting the shared nature of the task and promoting group cohesion. In lines 68 and 72 Rita voices her understanding of the resolution of the problem by using the continuer 'OK' signalling her acknowledgment, engagement and agreement with Silvia. By asking and answering, explaining and involving all the participants in decisions, Silvia scaffolds the learning of the others and encourages a positive social dimension during the course of the task, which leads to the creation of learning opportunities.

In contrast, Excerpt 2 shows how the learners Liliana, Rute, David and Carolina in Class 2 , completing the same task, fail to consult each other on decisions or provide explanations. 
(2)

\begin{tabular}{|c|c|c|}
\hline 85 & $\mathrm{~L} \& \mathrm{C}$ & we didn't knew that the \\
\hline 86 & $\mathrm{C}$ & train was late. (( read from the tasksheet $))$ \\
\hline 87 & $\mathrm{R}$ & $<{ }^{\circ}$ we didn't knew ${ }^{\mathrm{o}}>$ \\
\hline 88 & $\mathrm{D}$ & ${ }^{\circ}$ doesn' $t^{0}$ \\
\hline 89 & $\mathrm{~L}$ & we didn't KNOW \\
\hline 90 & $\mathrm{R}$ & >yes (.) we didn't know. yes (.) it's correct< \\
\hline 91 & C\&L & we didn't know, \\
\hline 92 & $\mathrm{R}$ & mmm' \\
\hline 93 & $\mathrm{C}$ & kno:w (.) we didn’t know \\
\hline 94 & $\mathrm{~L}$ & {$\left[{ }^{0}\right.$ when we write ()$\left.^{\circ}\right]$} \\
\hline 95 & $\mathrm{R}$ & [no it's correct.] (2) his life \\
\hline 96 & $\mathrm{C}$ & his life use to be (1) simpler (( reads from tasksheet)) \\
\hline 97 & $\mathrm{R}$ & $\underline{\text { use:d use:d }}$ \\
\hline 98 & $\mathrm{~L}$ & ${ }^{\circ}$ his life ${ }^{o}$ \\
\hline 99 & $\mathrm{C}$ & use:d \\
\hline 100 & $\mathrm{R}$ & use:d to be \\
\hline 101 & $\mathrm{C}$ & used \\
\hline 102 & $\mathrm{R}$ & $>$ used to be simpler. $<$ \\
\hline 103 & $\mathrm{~L}$ & mmhmm' \\
\hline
\end{tabular}

In line 88 David suggests 'doesn't' as a way of correcting this sentence but his suggestion is ignored and his opinion is not sought in the resolution of these two problem sentences (lines 89 and 97). In line 89 Liliana suggests 'didn't know' and this is accepted unconditionally by Carolina and Rute in lines 90 and 91 . No explanation is offered and none is sought. In line 97 Rute suggests substituting 'use' for 'used' in the next sentence for correction, which is accepted by the others although once again David is not consulted. This lack of interest in the opinions of peers could explain the lower level of peer correction in this task and ultimately leads to this task being less successful in terms of the creation of learning opportunities. Learners here would appear to be less engaged with the task, as there is no questioning, justification or explanation amongst group members. In addition, they seem to be uninterested in asking for or listening to the opinions of others. This would suggest a less cohesive group environment which may discourage a positive social dimension and where some group members may be treated unequally. 
In task 1 therefore it would appear that one explanation for the greater number of learning opportunities created by the learners in Class 1, was the fact that these students engaged in cohesive behaviour which created a more positive social dimension leading to greater cooperation between members to complete the task, a characterstic of cohesive groups (Ehrman \& Dornyei, 1998). Conversely, fewer learning opportunities were created by learners in the less cohesive group, Class 2 . There was a lack of engagement with the task and each other, which resulted in the creation of fewer learning opportunities, especially for David, the weaker member of the group.

\subsubsection{Task 6}

In task 6, an error correction and discussion task, learners in Class 1, the self-declared more cohesive group produced fewer learning opportunities than those in Class 2. Analysis of the interaction amongst these learners attempts to provide an explanation for this. Excerpt 3 shows how Neema and Iris, both students in class 1, fail to engage in interactional work to complete the error correction task.

(3)

\begin{tabular}{|c|c|c|c|}
\hline \multirow{2}{*}{$\rightarrow$} & 1 & $\mathrm{~N}$ & 'the first one I think it's correct'o if you won a lot of money (.) you would \\
\hline & 2 & & move house. \\
\hline$\rightarrow$ & 3 & I & yes \\
\hline$\rightarrow$ & 4 & $\mathrm{~N}$ & i think it's correct. (.) \\
\hline$\rightarrow$ & 5 & I & ${ }^{\text {oo }}$ correct. ok ${ }^{\text {oo }}$ \\
\hline \multirow[t]{4}{*}{$\rightarrow$} & & & second one, (.) what' would you do, if you didn't like the food your friend \\
\hline & 6 & $\mathrm{~N}$ & (.) cooked for you. ((reads question)) would. what \\
\hline & 7 & & would you do \\
\hline & 8 & & what would \\
\hline$\rightarrow$ & 9 & I & would. (.) yes. \\
\hline \multirow[t]{3}{*}{$\rightarrow$} & 10 & $\mathrm{~N}$ & you do (.) and this part is correct (.) the food your friend \\
\hline & 11 & I & cooked \\
\hline & 12 & & $<$ yo:ur frie:nd > \\
\hline$\rightarrow$ & 13 & $\mathrm{~N}$ & yes. \\
\hline \multirow[t]{2}{*}{$\rightarrow$} & 14 & I & yes. (1) ${ }^{\circ o}<$ what country would you vi:sit (1) if you co:uld $>^{\circ o}$ \\
\hline & 15 & $\mathrm{~N}$ & ${ }^{\circ o}$ travel $^{\circ o}(5)^{\circ o}<$ if you could travel $>^{o o}$ \\
\hline$\rightarrow$ & 16 & & (3) ${ }^{\circ o}$ if you could travel ${ }^{\text {oo }}$ (3) i think yes. (1) it's correct \\
\hline$\rightarrow$ & 17 & & (5) ${ }^{\circ}$ if you needed to borrow some money (.) who would you \\
\hline & 18 & & $\operatorname{ask}^{\mathrm{oo}}$ \\
\hline
\end{tabular}


In line 1 Neema reads the sentence for correction, thereby positioning herself as the task manager. This is followed immediately by Iris who agrees in line 3 that the sentence is correct, but fails to expand her turn to elaborate why. This is followed by both Neema and Iris again agreeing in lines 4 and 5, but again with no further expansion on the part of either. During the rest of the interaction neither learner comments on the opinions of their partner nor expands on their reasons for corrections. In addition there is no metalanguage, no repair, no questioning and a lack of engagement on the part of the learners with the task. There is a noticeable lack of continuers (Wong \& Waring, 2010), or other signs of phatic communication. The absence of continuers such as 'Oh', 'Yes', and 'Ah', which would signal increased engagement on the part of participants could suggest disinterest. The learners' utterances indicate a lack of a positive social dimension and resulted in a reduced number of learning opportunities. This lack of a positive social dimension can be more clearly seen later in the dialogue, illustrated in Excerpt 4.

(4)

$20 \mathrm{~N}$ if you friend had a (.) horrible haircut. (.) would you tell him or (.) or her.

21 yes. ok. (.) now question.(3) em: if you won.(.) a lot of money. (.) you would move house?

23 I (1) no, i think if i had,(.) first of all(.) i will pay (.) everything i need, (.)

24 for example (.) my (2) m: my ( ) bank, (.) or (.) or my (.)my job, and

25 (.) in (.) in final (.) i (.) ${ }^{\mathrm{o}} \mathrm{i}$ will buy a house $\mathrm{o}^{\mathrm{o}}$.

26 but i have credit.

$\rightarrow \quad 27 \quad \mathrm{~N} \quad$ uh:. (.) now (.) you can ask me.

$\rightarrow \quad 28$ I $\quad$ yes.((smiley voice) $)>$ if you won a lot of money you would

29 move house? $<$

$\rightarrow \quad 30 \quad \mathrm{~N} \quad>$ i i'd absolutely move house. $<$

$\rightarrow \quad 31 \quad \mathrm{I} \quad$ (laughs)

$\rightarrow \quad 32 \mathrm{~N} \quad<$ ah: in: a (.) in a:sia. asia. $>$

$\rightarrow \quad 33 \quad$ I $\quad$ yes ah. [move house and country].

$34 \mathrm{~N}<$ [i i ] yes(.) yes my house. i (.) love e: asia, (1) i love asia, a:

35 very interesting country(1) exciting (1) country(2)

$\rightarrow \quad 36 \quad$ continent?>

$\rightarrow \quad 37 \quad$ I continent

$38 \quad$ continent 


$\begin{array}{llll}\rightarrow & 39 & \text { N } & \text { i never stayed in asia. } \\ \rightarrow & 40 & \text { I } & \text { Mmm. } \\ \rightarrow & 41 & \text { N } & \text { i never (.) but i want to visit(.) some day. } \\ & 42 & \text { I } & \text { (2) what would you do, if you didn't like the food your friend } \\ 43 & \text { N } & \text { cooked for you. }\end{array}$

Throughout this dialogue Iris's comments in lines 23-26, 39 and 41, are not expanded, possibly due to the fact that they are met with news receipt responses from Neema in lines 27 and 40 (Wong \& Waring, 2010:71) which discourage elaboration. In addition their dialogue is characterised by frequent pauses due to their lack of interaction, and they finish the task more than 3 minutes earlier that other pairs and spend most of this time sitting silently waiting for the others to finish, which shows both a lack of social and behavioural engagement with the task (Philp \& Duchesne, 2016:7), and indicates a less cohesive relationship between these learners.

In contrast, Excerpt 5 shows how João and Carlos, both learners in Class 2, the less cohesive group, carry out the same task, and illustrates the use of humour on the part of this dyad.

(5)

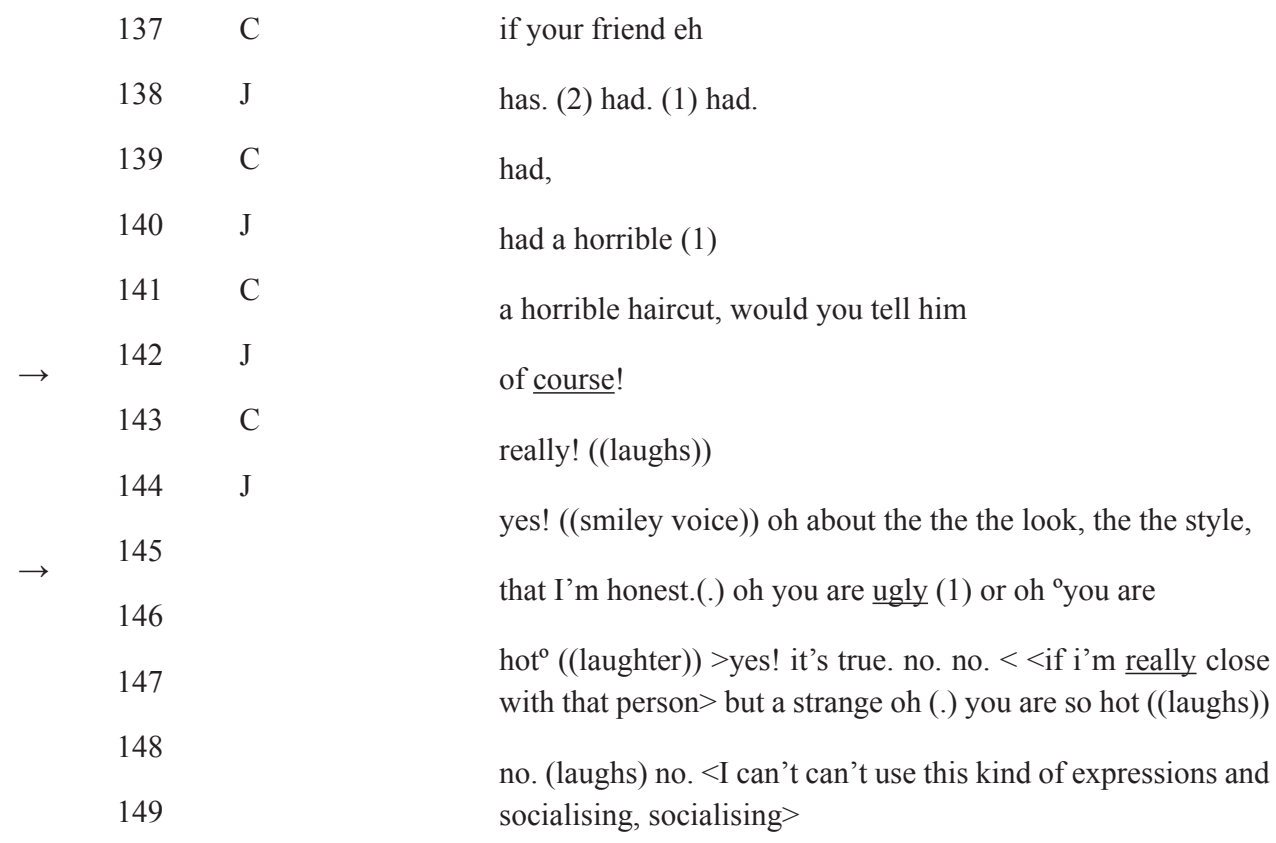




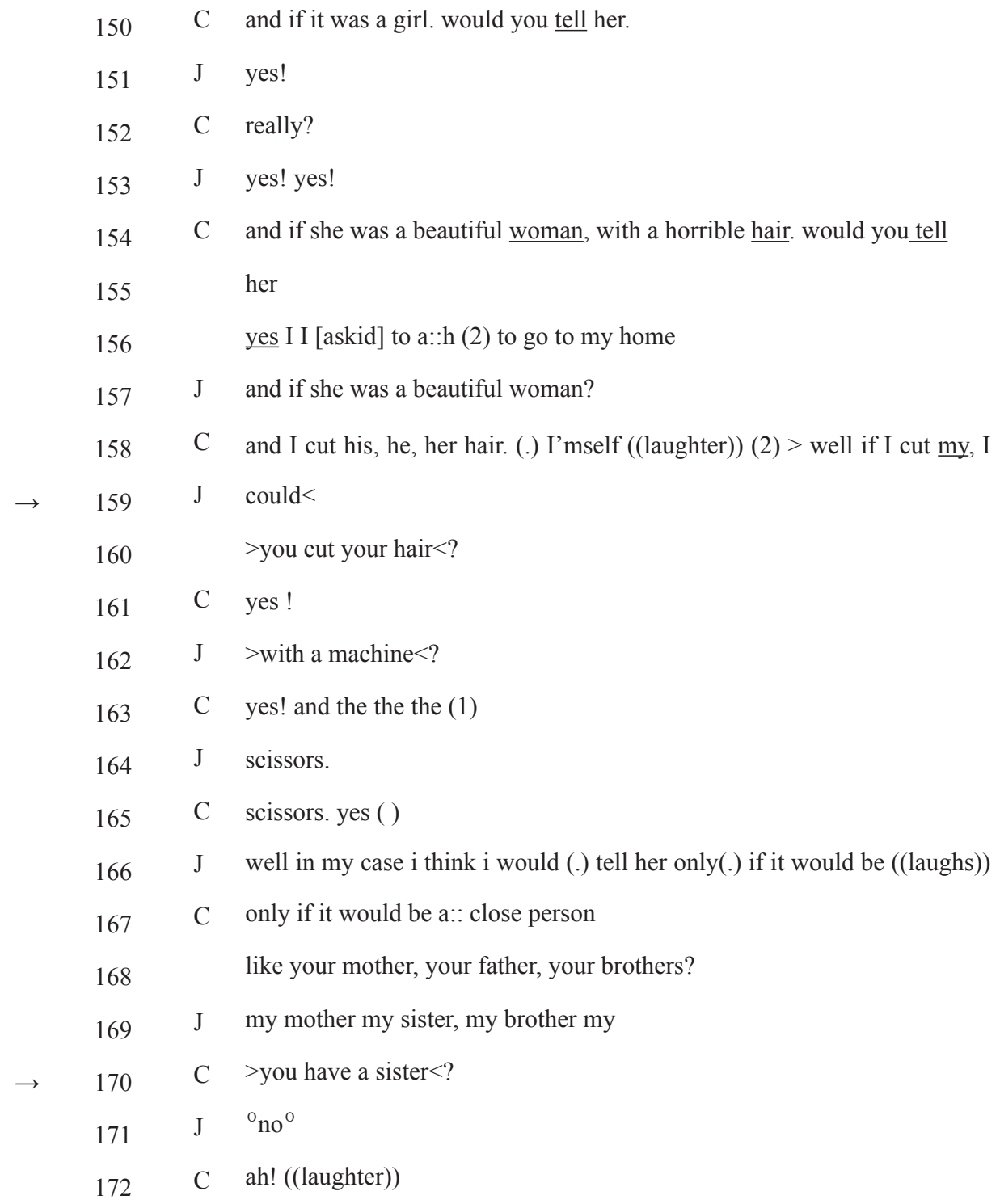

Here João and Carlos together construct a humorous imaginary scenario from lines 144159. Then, in line 170, João is involved in a sequence misfit (Reddington and Waring, 2015: 13) by responding to Carlos's comment on his sister, rather than focusing on the topic under discussion. As noted by Reddington and Waring, this type of extension often has a subversive overtone, in this case unmasking Carlos as telling lies for the purpose of fulfilling the task. It would therefore seem that the learners here are adept at 'being playful' in the classroom 
and can bring their real world 'playful' personas into peer interaction. Their humorous talk serves to make the language learning experience more enjoyable and motivating, and creates both a positive social environment and learning opportunities.

\subsubsection{Task 7}

Task 7, the second task in Term 3, is a discussion activity related to how people react in tricky situations. Students from Class 1 have difficulty starting the task and sit silently for 1 minute 6 seconds. They then silently read the questions, resulting in an additional 23 seconds silence before starting their discussion, and there are additional 24 and 39 second pauses between discussing questions 2 and 3 respectively. Silence can be thought of as a sign of opting out of social engagement, suggests participants do not feel sufficiently at ease with each other to engage in communication, and is a "major obstacle" to the development of a cohesive group (Ehrman \& Dornyei, 1998:116). There seems to be little rapport between learners, who limit their interaction to the task at hand.

In contrast, Excerpt 6 shows the dyad Deolinda and Eva in Class 2 taking part in task 7 , and illustrates how these learners produce a collaborative overlap style indicative of their alignment to the task, characterised by one speaker chiming in to complete the other's utterances. This can be seen in lines 58-62, 65 to 69 and lines 116-125, and is thought to indicate involvement by "giving the impression of shared views, opinions, attitudes and knowledge" (Eder, 1988: 225) and a sense of rapport between speakers (Tannen, 1990: 196), showing the cohesive ties which exist between these two speakers. Moreover these learners repeat the utterances of the other in lines 66-67,117-118, and 122-123. Other repetition is used to engage with and legitimise each other's contributions and, according to Tannen (1987: 584), serves to "show acceptance of others' utterances and their participation". It is suggested that this positive social dimension is instrumental in leading to the greater provision of learning opportunities by these Class 2 students when compared to the less positive social dimension of the interaction of Class 1 students.

(6)

55 D but (4) but the neighbours, can $^{\circ}$ get $^{\circ}($.) can be (.) can stay angry with her

56 yes yes $(2)<$ usually: the first thing: you should do (.) it's to go (.) to

$\begin{array}{llll} & 57 & \text { E } & \text { [talk:]> } \\ \rightarrow & 58 & & \quad \text { [and talk] and explain } \\ \rightarrow & 59 & \text { D } & <\text { <with nei: ghbours. } \\ \rightarrow & 60 & \text { E } & \text { and ask to (.) play the sound } \\ \rightarrow & 61 & \text { D } & \text { yes (.) louder? no (5) down? } \\ \rightarrow & 62 & \text { E } & \text { down? I already } \\ & 63 & \text { D } & <\text { uh: (2) and [the:n]> }\end{array}$




\begin{tabular}{|c|c|c|}
\hline 64 & $\mathrm{E}$ & {$[\text { down }]^{\circ}$ but I don't ${ }^{\circ}$} \\
\hline$\rightarrow$ & $\mathrm{D}$ & $<[$ if: they $]]$ don't: agree: you should: $>$ \\
\hline$\rightarrow$ & $\mathrm{E}$ & talk \\
\hline 67 & $\mathrm{D}$ & talk: \\
\hline$\rightarrow$ & $\mathrm{E}$ & to the police \\
\hline 69 & $\mathrm{D}$ & yes (.) from the police \\
\hline 116 & $\mathrm{E}$ & i don't know (4) the fi:rst: is no:t ve:ry \\
\hline 117 & $\mathrm{D}$ & complicated \\
\hline 118 & $\mathrm{E}$ & complicated to (.) yes(.) its not very complicated to: yourself \\
\hline 119 & $\mathrm{D}$ & but \\
\hline 120 & $\mathrm{E}$ & yes to to others \\
\hline 121 & $\mathrm{D}$ & to other per persons and it:s \\
\hline 122 & $\mathrm{E}$ & ${ }^{\circ}$ complicated $^{\circ}$ \\
\hline 123 & $\mathrm{D}$ & complicated but: the second (.) and third one (.) are: \\
\hline 124 & $\mathrm{E}$ & worse \\
\hline 125 & $\mathrm{D}$ & and the se:cond are: violent \\
\hline
\end{tabular}

\section{Discussion and Conclusion}

One objective of this study was to investigate how learning opportunities were talked into being during peer interactions in cohesive and less cohesive classes within a sociocognitive framework. Analysis of talk in interaction showed that students in both the more and less cohesive class were able to work in their zones of proximal development during pair or group work and gain further understanding of the language through the learning opportunities created.

Contrary to expectations, more learning opportunities were created in interaction amongst students in Class 2, the least cohesive group. Qualitative analysis of the talk in interaction amongst these learners revealed how a positive social dimension, which is more characteristic of a cohesive group, was created through interaction, leading to the creation of more learning opportunities. Analysis also showed how interactions amongst learners in Class 1, the self-declared more cohesive class, at times discouraged a positive social dimension, and how these learners at times engaged in less cohesive behaviour resulting in the creation of fewer learning opportunities. 
Thus, contrary to what has been reported previously in the literature related to other small groups, in language classes the nature of the cohesive behaviour of learners in small groups and the resulting positive social dimension may be important to the provision of learning opportunities, rather than the cohesive nature of the group as a whole. This is in agreement with the recent work of Baralt, Gurzynski-Weiss and Kim, (2016: 234), who similarly emphasise the importance of learners' affective and social engagement during peer interaction on their creation of learning opportunities.

Through this type of enquiry, a better understanding can be developed of the ways group cohesion and the social dimension influence learners' engagement with the classroom experience and the learning process. This analysis has contributed to an understanding of learning in peer interaction, and shows how learning is socially deployed and configured through social interaction. The locally constructed nature of interaction allows for different potentials for learning, with the cohesive nature of the relationship between group members being an important factor in the creation of opportunities for learning. Further research could profitable adopt a multiple case-study approach to allow for a more thorough understanding of how cohesion and the social dimension influence learning within small groups over the period of an academic year.

\section{REFERENCES}

Arnold, J., and Brown, H.D. (1999). "A map of the terrain", in J. Arnold (ed.), Affect in Language Learning. Cambridge: Cambridge University Press, 1-24.

Baralt. M., Gurzynski-Weiss, L., and Kim, Y. (2016). "Engagement with the language: How examining learners' affective and social engagement explains successful learner-generated attention to form", in M. Sato and S. Ballinger (eds.), Peer Interaction and Second Language Learning. Amsterdam: John Benjamins Publishing Company, 209-239.

Canico, M. (2015). "Assessing Learning Opportunities in EFL classroom interaction: What can conversation analysis tell us?", in RELC Journal, 46, 2: 115-129.

Chang, L. (2007). "The influences of group processes on learners' autonomous beliefs and behaviours", in System, 3, 3: 322-337.

Clement, R., Dornyei, Z., and Noels, K.A. (1994). "Motivation, self-confidence, and group cohesion in the foreign language classroom", in Language Learning, 44, 3: 417-448.

Council for Cultural Co-operation Education Committee. (2001). Common European Framework of Reference for Languages: Learning, Teaching, Assessment. Cambridge: Cambridge University Press.

Eder, D. (1988). "Building cohesion through collaborative narration", in Social Psychology Quarterly, 51, 3: 225-235.

Ehrman, M., and Dornyei, Z. (1998). Interpersonal Dynamics in Second Language Education. Thousand Oaks, London and New Delhi: Sage Publications.

Ellis, R. (2003). Task Based Language Learning and Teaching. Oxford: Oxford University Press.

Evans, C., and Dion, K. (1991). "Group cohesion and performance: a metaanalysis", in Small Group Behaviour, 22, 2: 175-186.

Firth, A., and Wagner, J. (2007). "Second/foreign language learning as a social accomplishment: Elaborations on a reconceptualized SLA", The Modern Language Journal, 91,s1: 800-819.

Forsyth, D. (1991). Group Dynamics. Belmont, CA: Wadsworth Publishing. 
Foster, P., and Ohta, A.S. (2005). "Negotiation for meaning and peer assistance in second language classrooms", in Applied Linguistics, 26, 3: 402-430.

Hellermann, J., and Pekarek Doehler, S. (2010). "On the contingent nature of language-learning tasks", in Classroom Discourse, 1, 1: 25-45.

Krashen, S. (1982). Principles and Practice in Second Language Acquisition. Oxford: Pergamon.

Larsen-Freeman, D. (2010). "The dynamic co-adaptation of cognitive and social views: A complexity theory perspective", in R. Batstone (ed.), Sociocognitive Perspectives on Language Use and Language Learning. Oxford: Oxford University Press, 40-53.

Leontiev, A. (1981). Psychology and the Language Learning Process. Oxford: Pergamon Press.

Levine, J.M., and Moreland, R.L. (1990). "Progress in small group research", in Annual Review of Psychology, 41: 585-543.

Long, M. (1996). "The role of the linguistic environment in second language acquisition", in W. Ritchie and T. Bhatia (eds.), Handbook of Second Language Acquisition. San Diego, CA: Academic Press, 413-468.

Lyster, R., Saito, K., and Sato, M. (2013). "Oral corrective feedback in second language classrooms", in Language Teaching, 46, 1: 1-40.

Mondada, L., and Pekarek Doehler, S. (2004). "Second language acquisition as situated practice: Task accomplishment in the French second language classroom", in The Modern Language Journal, 88, 4: 501-518.

Ohta, A.S. (2001). Second language Acquisition Processes in the Classroom: Learning Japanese. Mahwah, NJ: Lawrence Erlbaum.

Philp, J., Adams, R., and Iwashita, N. (2014). Peer Interaction and Second Language Learning. Oxford: Routledge.

Philp, J., and Duchesne, S. (2016). "Exploring engagement in tasks in the language classroom", in Annual Review of Applied Linguistics, 36: 50-72.

Reddington, E., and Waring, H.Z. (2015). "Understanding the sequential resources for doing humor in the language classroom", in Humor, 28, 1: 1-23.

Sato, M., and Ballinger, S. (2016). "Introduction: Understanding peer interaction ", in M. Sato and S. Ballinger (eds.), Peer Interaction and Second Language Learning. Amsterdam: John Benjamins Publishing, 1-30.

Seedhouse, P. (2004). The Interactional Architecture of the Language Classroom: A Conversation Analysis Perspective. Oxford: Blackwell.

Seedhouse, P. (2005). "Conversation analysis and language learning”, in Language Teaching, 38, 4:165-187.

Senior, R. (1997). "Transforming language classes into bonded groups", in ELT Journal, 51, 1: 3-11.

Slavin, R.E. (1996). "Research on cooperative learning and achievement: What we know, what we need to know", in Contemporary Educational Psychology, 21, 1: 43-69.

Swain, M. (1995). "Three functions of output in second language learning", in G. Cook and B. Siedlhofer (eds.), Principle and Practice in Applied Linguistics: Studies in honour of H.G. Widdowson. Oxford: Oxford University Press, 125-144.

Swain, M. (2010). “'Talking-it-through': Languaging as a source of learning”, in R. Batstone (ed.), Sociocognitive Perspectives on Language Use and Language Learning. Oxford: Oxford University Press, 112- 130.

Swain, M., and Lapkin, S. (1998)." Interaction and second language learning: Two adolescent French immersion students working together", in The Modern Language Journal, 82, 3: 320-337.

Swezey, R., Meltzer, A., and Salas, E. (1994). "Some issues involved in motivating teams", in H. O’Neill and M. Drillings (eds.), Motivation: Theory and Research. Hillsdale, NY: Erlbaum, 141-169. 
Tannen, D. (1990). You Just Don't Understand: Men and Women in Conversation. New York: Ballantine Books.

Vygotsky, L. (1987). The Collected Works of L.S. Vygotsky: Volume 1. Thinking and Speaking. New York: Plenum Press.

Wajnryb, R. (1990). Grammar Dictation. Oxford: Oxford University Press.

Wong, J., and Waring, H.Z. (2010). Conversation Analysis and Second Language Pedagogy. Abingdon: Routledge.

\section{APPendix 1. STUDENT QUeSTiOnNAIRE}

\section{Group cohesion/ Grupo coesão}

The statements below attempt to describe some of your feelings about your current class. Please decide if you agree or disagree with the statements and tick $(\sqrt{ })$ ONE of the boxes according to how you feel.

O quadro seguinte apresenta algumas frases para descrever os seus emoções acerca da sua turma. Por favor decida se concorda ou discorda com as frases e assinale com um certo $(\sqrt{ })$ um dos quadrados de acordo com a sua percepção.

\begin{tabular}{|c|c|c|c|c|c|}
\hline \multirow{2}{*}{ Statements } & \multicolumn{5}{|c|}{ Your opinion/Sua opinião } \\
\hline & $\begin{array}{l}\text { False } \\
\text { Falso }\end{array}$ & $\begin{array}{l}\text { Somewhat } \\
\text { true } \\
\text { Alguma } \\
\text { verdade }\end{array}$ & Neutral & $\begin{array}{c}\text { True } \\
\text { Verdadeiro }\end{array}$ & $\begin{array}{l}\text { Very True } \\
\text { Muito ver- } \\
\text { dadeiro }\end{array}$ \\
\hline $\begin{array}{l}\text { 1. If I were in another class, I would want } \\
\text { that class to have students very similar to the } \\
\text { classmates I have now. } \\
\text { Se eu estivesse noutra turma eu iria querer que } \\
\text { ela tivesse alunos muito similares aos colegas } \\
\text { que tenho agora. }\end{array}$ & & & & & \\
\hline $\begin{array}{l}\text { 2. This class is composed of people who get } \\
\text { on well. } \\
\text { Esta turma é composta por pessoas que se dão } \\
\text { bem. }\end{array}$ & & & & & \\
\hline $\begin{array}{l}\text { 3. I know the names of all my classmates. } \\
\text { Conheço os nomes de todos os colegas da } \\
\text { aula. }\end{array}$ & & & & & \\
\hline $\begin{array}{l}\text { 4. I am satisfied with my class. } \\
\text { Estou satisfeita com a minha turma. }\end{array}$ & & & & & \\
\hline
\end{tabular}




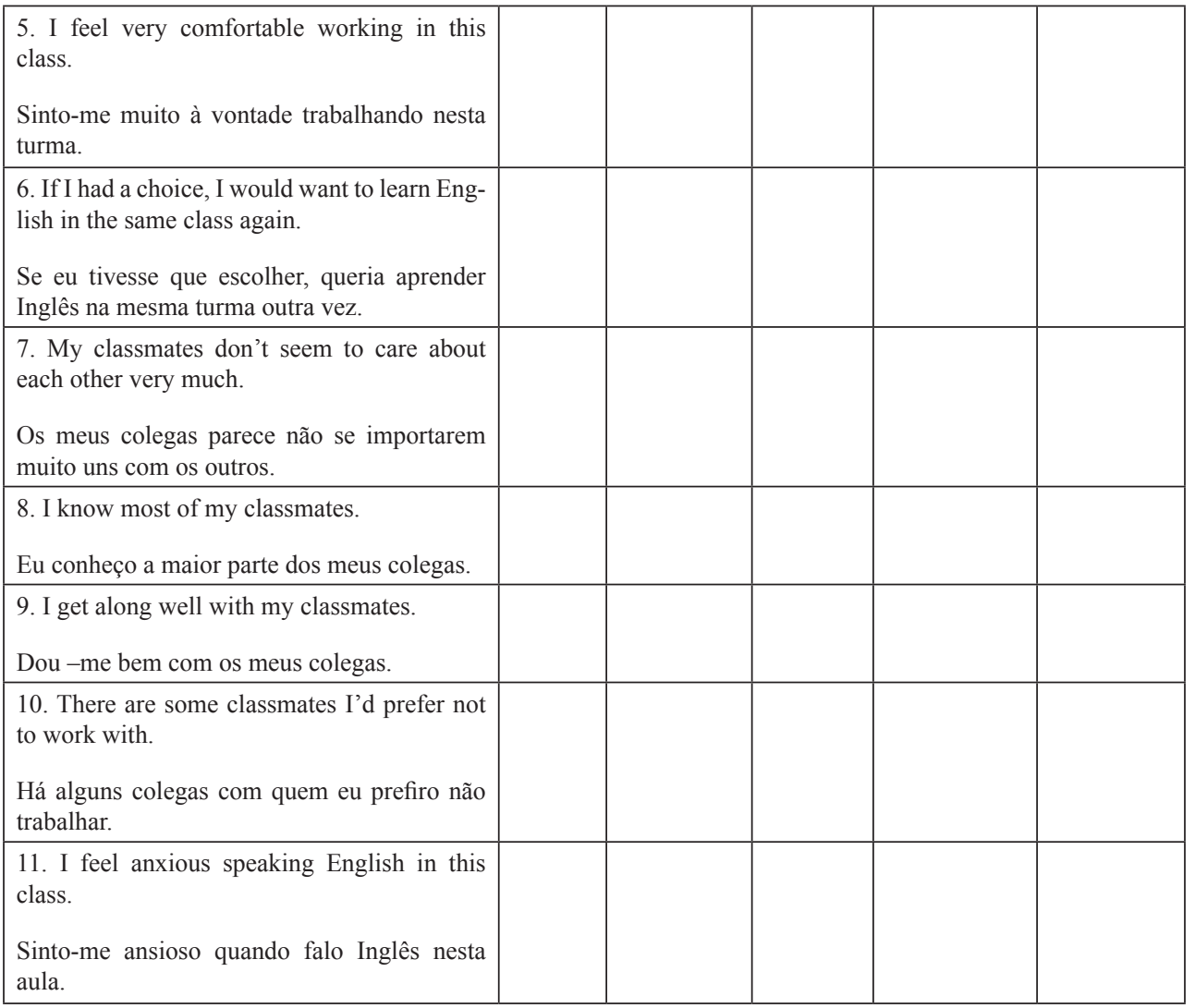

\section{Appendix 2. Teacher QUestionnaire}

\section{Group cohesion}

The statements below attempt to describe some of your feelings about this class. Please decide if you agree or disagree with the statements and tick $(\sqrt{ })$ ONE of the boxes according to how you feel.

\begin{tabular}{|l|c|c|c|c|c|}
\hline \multicolumn{1}{|c|}{ Statements } & \multicolumn{5}{|c|}{ Your opinion } \\
\hline & $\begin{array}{c}\text { Not } \\
\text { true }\end{array}$ & $\begin{array}{c}\text { Somewhat } \\
\text { true }\end{array}$ & Neutral & True & $\begin{array}{c}\text { Very } \\
\text { True }\end{array}$ \\
\hline 1. The group is tolerant of all its members. & & & & & \\
\hline $\begin{array}{l}\text { 2. Some group members will not cooperate to } \\
\text { perform tasks. }\end{array}$ & & & & & \\
\hline
\end{tabular}




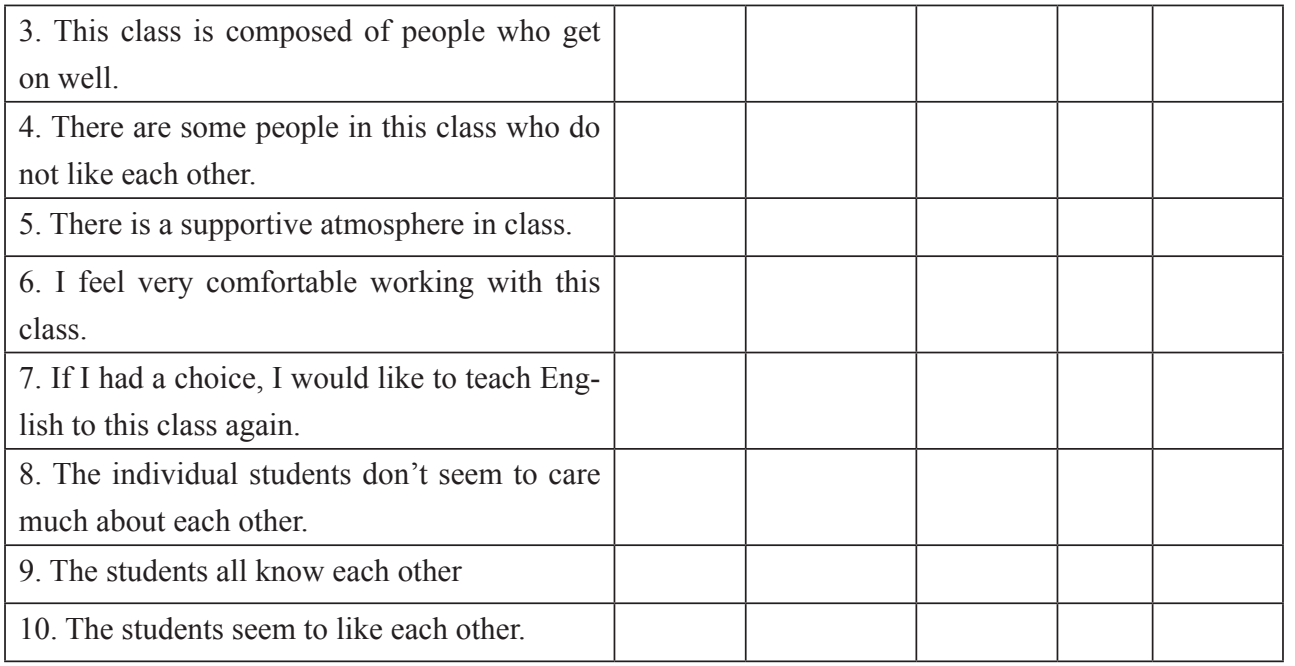

ApPendix 3. TRAnSCRiption CONVEntions (adapted from Seedhouse, 2004: 267-269 and Ohta, 2001:27)

\begin{tabular}{|c|c|}
\hline : & Elongation of a syllable \\
\hline (.) & Brief untimed pause \\
\hline$(3.2)$ & Interval between utterances (in seconds) \\
\hline$\underline{\text { word }}$ & Speaker emphasis \\
\hline$!$ & Animated or emphatic tone \\
\hline CAPITALS & Loud sound relative to surrounding talk \\
\hline$\circ \circ$ & Utterances which are noticeably quieter than surrounding talk \\
\hline ০০০ & Whispered utterances \\
\hline$<>$ & Talk produced slowly and deliberately \\
\hline$><$ & Talk produced more quickly than surrounding talk \\
\hline ( ) & Unclear or unintelligible speech or attempt to transcribe such speech \\
\hline$\rightarrow$ & A feature of special interest \\
\hline $\operatorname{sim}((\operatorname{tr} .:$ yes $))$ & $\begin{array}{l}\text { Non-English words are written in italics and followed by English translation in } \\
\text { double brackets }\end{array}$ \\
\hline
\end{tabular}




\begin{tabular}{|l|l|}
\hline T: & Teacher \\
LL: & $\begin{array}{l}\text { Unidentified learner } \\
\text { Several or all learners simultaneously }\end{array}$ \\
[[ & $\begin{array}{l}\text { Indicates overlap with portion in the next turn that is similarly bracketed } \\
\text { Indicates overlap with portion in the next turn that is similarly bracketed when } \\
\text { the single bracket is used in the previous line and or turn so there will be no } \\
\text { confusion regarding what brackets correspond to. } \\
\text { Comments }\end{array}$ \\
$(())$ & $\begin{array}{l}\text { An approximation of the right sound in the case of inaccurate pronunciation } \\
\text { Rising intonation } \\
\text { [ finished] }\end{array}$ \\
$\begin{array}{l}\text { Slight rise in intonation } \\
\text { Falling intonation } \\
\downarrow\end{array}$ & $\begin{array}{l}\text { Accentuated rise in intonation } \\
\text { Accentuated fall in intonation }\end{array}$ \\
\hline
\end{tabular}

